\title{
Kilka uwag dotyczących opodatkowania rolnictwa w Polsce w kontekście Europejskiego Zielonego Ładu
}

\section{Zagadnienia wstępne}

Polityka subsydiowania rolnictwa jest częścią współczesnej gospodarki i nieodłącznym elementem ekonomii krajów rozwiniętych. Jednocześnie system podatkowy, odmienny w poszczególnych krajach, z reguły zawiera szereg elementów uprzywilejowujących rolnictwo. W Polsce powszechny system podatkowy (podatek dochodowy) nie obejmuje typowej działalności rolniczej. Niewielkie obciążenia fiskalne dochodu występują tylko w opodatkowaniu działów specjalnych produkcji rolnej ${ }^{1}$. Wielokrotnie w ostatnich kilkudziesięciu latach postulowano zmiany systemu opodatkowania rolnictwa ${ }^{2}$. Jednak w podstawowej konstrukcji podatku rolnego nic się nie zmieniło od 1984 r., tj. od wejścia w życie ustawy z 15 listopada 1984 r. o podatku rolnym ${ }^{3}$. Inne podatki mają zaś w rolnictwie charakter marginalny.

* Uniwersytet w Białymstoku.

${ }^{1}$ Szerzej: J. Bieluk, Dzialy specjalne produkcji rolnej. Problemy prawne, Białystok 2013.

2 Zob. m.in. M. Podstawka, Opodatkowanie rolnictwa i perspektywy jego zmian $w$ Polsce, Warszawa 1995; M. Burzec, P. Smoleń, Nowy model opodatkowania rolnictw w Polsce, w: P. Smoleń (red.), Opodatkowanie rolnictwa w Polsce. Weryfikacja założeń. Perspektywa zmian, Warszawa 2018; R.I. Dziemianowicz, Efektywność systemu opodatkowania rolnictwa, Białystok 2007; K. Gruziel, Stan i kierunki zmian w opodatkowaniu gospodarstw rolniczych, Warszawa 2008.

${ }^{3}$ Ustawa z 15 listopada 1984 r. o podatku rolnym (t.j. Dz. U. z 2020 r., poz. 333). Ustawa o podatku rolnym była wielokrotnie nowelizowana, m.in. wyłączono opodatkowanie działów specjalnych produkcji rolnej z opodatkowania podatkiem rolnym, jednak zasadnicza konstrukcja podatku obciążającego grunt rolny pozostała bez zmian. 
Istotnym elementem polityki rolnej Unii Europejskiej stają się założenia Zielonego Ładu oraz strategii „Od pola do stołu”. Celem rozważań jest określenie roli systemu opodatkowania rolnictwa, jaką mógłby on odgrywać we wdrażaniu nowych rozwiązań służących przede wszystkim minimalizowaniu wpływu produkcji rolnej na środowisko, ale także w kształtowaniu ustrojowego modelu rolnictwa opartego na gospodarstwach rodzinnych. System podatkowy w rolnictwie jest odporny na zmiany. Okazją do jego zreformowania mógłby być Zielony Ład, przy którego wdrażaniu można by stworzyć mechanizmy fiskalne stymulujące rolników do działań proekologicznych i proklimatycznych.

\section{System podatkowy w polskim rolnictwie}

Od momentu wprowadzenia podatków dochodowych do systemu podatkowego w Polsce $\mathrm{z}$ ich zakresu wyłączone są dochody $\mathrm{z}$ rolnictwa ${ }^{5}$. Zgodnie z ustawami o podatkach dochodowych działalność rolnicza nie jest nimi objęta. Na mocy art. 2 ust. 1 obu ustaw do przychodów z działalności rolniczej, z wyjątkiem przychodów z działów specjalnych produkcji rolnej, nie stosuje się przepisów tych ustaw. Podatek rolny jest podatkiem anachronicznym, niedostosowanym do współczesnych rozwiązań, nie spełnia prawie żadnej roli stymulującej i ma niewielkie znaczenie fiskalne.

$\mathrm{Z}$ różnych powodów, przede wszystkim politycznych, podatek rolny trwa praktycznie niezmieniony od 1984 r. Przetrwał nawet zmiany ustroju. W doktrynie panuje zgoda, że podatek rolny powinien być zreformowany, że należy wprowadzić podatek dochodowy w rolnictwie (choć jego zakres wymaga ustalenia). Literatura na ten temat jest obszerna, a stanowisk broniących podatku rolnego praktycznie nie ma.

Próbę wyjaśnienia trwałości konstrukcji opodatkowania rolnictwa podjął Trybunał Konstytucyjny (TK) w wyroku z 26 października 2010 r. wydanym w sprawie dotyczącej motywów nieobjęcia rolników podatkiem dochodowym w 1991 r. $^{6}$ TK wskazał: „Przesłanką zachowania takiego unormowania $\mathrm{w}$ zakresie opodatkowania rolników u progu transformacji ustrojowej

${ }^{4} \mathrm{https} / /$ ec.europa.eu/info/strategy/priorities-2019-2024/european-green-deal_pl [dostęp: 12.10.2021].

${ }^{5}$ Regulacja ta pozostaje niezmieniona od wejścia w życie obu ustaw o podatku dochodowym, tj. ustawy z 26 lipca 1991 r. o podatku dochodowym od osób fizycznych (t.j. Dz. U. z 2021 r., poz. 1128) i ustawy z 15 lutego 1992 r. o podatku dochodowym od osób prawnych (t.j. Dz. U. z 2021 r., poz. 1800).

${ }^{6}$ Wyrok TK z 26 października 2010 r., sygn. akt: K 58/07, OTK Seria A, 2010, nr 8, poz. 80. 
w 1991 r. było panujące wówczas przekonanie, że ówczesne rozdrobnienie indywidualnych gospodarstw rolnych i ich zacofanie doprowadziły do znacznie niższej wydajności i opłacalności pracy w rolnictwie niż poza nim. Miało to też wynikać z dominującego naturalnego charakteru tej gospodarki z przeznaczeniem efektów produkcji na potrzeby rolników i ich rodzin, z ograniczonym jej udziałem w rozwiniętych procesach rynkowych. Ustawodawca zakładał, że ówczesny poziom rolników pracujących na granicy opłacalności nie pozwoli też na sprostanie przez nich procedurom precyzyjnego ustalania ich przychodów, kosztów i rzeczywistego dochodu z ich działalności rolniczej, co miało być warunkiem szerokiego objęcia gospodarczej działalności indywidualnych rolników obowiązkiem podatkowym w zakresie podatku dochodowego od osób fizycznych. Argumentacja ta podnoszona jest do dzisiaj w dyskusjach na temat projektów ustawodawczych dotyczących zmian systemu ich opodatkowania i modyfikacji systemu KRUS"7.

Jak słusznie zauważa TK w powołanym wyżej wyroku, analizując finansowanie ubezpieczenia zdrowotnego, ale odnosząc się też do systemu podatkowego: „populacja rolników prowadzących działalność gospodarczą w zakresie rolnictwa jest dzisiaj (w przeciwieństwie do sytuacji w $1991 \mathrm{r}$.) bardzo zróżnicowana. Obejmuje - jak wykazano w literaturze powołanej w części III pkt 7 uzasadnienia wyroku - dużą liczbę osób o dochodach nieodbiegających od poziomu dochodów osób będących podatnikami podatku dochodowego od osób fizycznych, jednostki o bardzo wysokich dochodach oraz nadal pokaźną liczbę osób prowadzących gospodarstwa rolne o bardzo niskiej wydajności i dochodowości”. Konkludując, TK zaś stwierdza: „Zdolność opłatowa tych trzech grup rolników objętych dziś jednolitym finansowaniem ich ubezpieczenia zdrowotnego przez budżet państwa jest w rzeczywistości zasadniczo różna, co czyni zaskarżoną regulację (art. 86 ust. $2 \mathrm{w}$ związku $\mathrm{z}$ art. 86 ust. 1 pkt 1 ustawy zdrowotnej) niezgodną $\mathrm{z}$ art. 32 ust. $1 \mathrm{w}$ związku $\mathrm{z}$ art. 84 i art. 2 Konstytucji”. Prowadzi to do wniosku, iż niezgodne z Konstytucją $\mathrm{RP}^{8}$ jest zobowiązanie budżetu państwa do finansowania składek na ubezpieczenie zdrowotne wszystkich wskazanych w nim rolników i ich domowników, podlegających ubezpieczeniu społecznemu rolników z mocy ustawy, prowadzących działalność rolniczą bez względu na wysokość osiąganych przez nich przychodów.

${ }^{7}$ TK powołuje się na następujące publikacje: M. Wasilewski, K. Gruziel, Podatek dochodowy w indywidualnych gospodarstwach rolniczych - koncepcja i skutki, „Zagadnienia Ekonomiki Rolnej" 2008, nr 1; J.S. Zegar (red.), Sytuacja ekonomiczna polskiego rolnictwa po akcesji do Unii Europejskiej, Warszawa 2009.

${ }^{8}$ Konstytucja Rzeczypospolitej Polskiej z 2 kwietnia 1997 r. (Dz. U. Nr 78, poz. 483). 
Wskazany wyrok zapadł 11 lat temu. Z jego konkluzji wynika, że obecnie obowiązujący system opodatkowania rolników, bez względu na ich dochody (z wyjątkiem opodatkowania działów specjalnych produkcji rolnej), należy uznać za niezgodny z Konstytucją RP. Już wtedy Trybunał Konstytucyjny dostrzegał wyraźnie, iż argumentacja dotycząca niemożności ustalania dochodów rolników jest anachroniczna. Jednak mimo powszechnego doktrynalnego konsensusu dotyczącego konieczności zmian nie są nawet podejmowane próby reformy systemu opodatkowania rolnictwa. Co prawda w 2013 r. przygotowano w Ministerstwie Finansów wstępne założenia do projektu ustawy o podatku dochodowym od osób fizycznych z działalności rolniczej oraz o zmianie innych ustaw, jednak nie podjęto nad nim bardziej zaawansowanych $\operatorname{prac}^{9}$.

\section{Opodatkowanie a Zielony Ład w rolnictwie}

Oczywiste jest, iż działalność człowieka oddziałuje na klimat i nie jest to oddziaływanie korzystne. Zatrzymanie globalnego ocieplenia jest największym wyzwaniem stojącym obecnie przed ludzkością ${ }^{10}$. Zmiany klimatu, z jakimi mamy dziś do czynienia, nie wystąpiły dotąd w historii ludzkości. Część z nich, jak chociażby ciągły wzrost poziomu mórz, jest nieodwracalna nawet w długiej perspektywie. Jak wskazuje raport IPCC „Climate Change 2021: the Physical Science Basis”, konieczne więc są szybkie, zdecydowane $i$ ambitne działania na rzecz redukcji emisji dwutlenku węgla i innych gazów cieplarnianych. Jest to jedyny sposób, aby zatrzymać zmiany klimatyczne. Należy jednak przebudować w tym celu cały system prawny. Unia Europejska określiła w ramach Europejskiego Zielonego Ładu, że Europa do 2050 r. stanie się pierwszym neutralnym dla klimatu kontynentem ${ }^{11}$. Rolnictwo w sposób naturalny jest częścią Europejskiego Zielonego Ładu. Jako cele w zakresie europejskiego systemu rolno-żywnościowego ustalono: 1) zmniejszenie śladu środowiskowego i klimatycznego związanego z systeblicznej.

${ }^{9}$ Projekt nie został upubliczniony, jest dostępny tylko w trybie dostępu do informacji pu-

${ }^{10}$ Literatura przedmiotu jest $\mathrm{w}$ tym zakresie bardzo bogata. Warto wymienić tu książki, które spotkały się z dużym odzewem społecznym: J.S. Foer, Klimat to my. Ratowanie planety zaczyna się przy śniadaniu, Warszawa 2020; N. Klein, To wszystko zmienia. Kapitalizm kontra klimat, Warszawa 2020; jak również ostatni raport IPCC, który nie pozostawia złudzeń w kwestii wpływu działań człowieka na klimat - streszczenie: https://www.ipcc.ch/report/ar6/wg1/downloads/report/ IPCC_AR6_WGI_SPM.pdf [dostęp: 12.10.2021] i pełen raport: https://www.ipcc.ch/report/ar6/ wg1/downloads/report/IPCC_AR6_WGI_Full_Report.pdf [dostęp: 12.10.2021].

${ }^{11} \mathrm{https} / /$ ec.europa.eu/clima/policies/eu-climate-action_pl [dostęp: 12.10.2021]. 
mem żywnościowym, 2) wzmocnienie odporności systemu żywnościowego Unii Europejskiej, 3) przewodzenie globalnej transformacji w kierunku konkurencyjnej zrównoważoności „od pola do stołu”"

Jak wskazuje się w odtajnionym niedawno raporcie OECD na temat opodatkowania rolnictwa: „Motywacją leżącą u podstaw tego przeglądu opodatkowania w rolnictwie była poprawa bazy dowodowej dotyczącej wpływu różnych polityk podatkowych na główne czynniki napędzające produktywność i zrównoważony rozwój rolnictwa - innowacje, zmiany strukturalne, wykorzystanie zasobów naturalnych i zmiany klimatyczne"13.

Podkreśla się również konieczność lepszego zrozumienia bezpośredniego i pośredniego wpływu przepisów podatkowych na rolnictwo oraz bardziej regularnej oceny wpływu polityki podatkowej na rolnictwo. Konieczne jest więc przyjrzenie się, w jaki sposób system podatkowy może wpływać na realizację powyższych celów.

W literaturze wymienia się różne podejścia do funkcji podatków. Można mówić o funkcji fiskalnej, redystrybucyjnej i stymulacyjnej ${ }^{14}$. W teorii ekonomicznej występują dwa podejścia do roli podatku ${ }^{15}$ : pierwsze zakłada wyłącznie jego fiskalną rolę, drugie - łączy rolę fiskalną z realizacją istotnych celów pozafiskalnych, np. pobudzanie inwestycji, ochronę środowiska naturalnego, korygowanie nadmiernego zróżnicowania dochodów w społeczeństwie $^{16}$. System podatkowy powinien przy tym realizować zasadę sprawiedliwości podatkowej. Polski system podatkowy jako całość, a w szczególności skomplikowana konstrukcja podatku dochodowego od osób fizycznych, jako zasadę przyjmuje stymulacyjną rolę obciążeń fiskalnych. Szereg ulg, zwolnień i zróżnicowane stawki podatkowe to elementy złożonego systemu mającego realizować, oprócz dostarczania dochodów budżetowi, określone funkcje pozafiskalne.

W Polsce podatek rolny, jako podstawowe obciążenie finansowe rolnictwa, nie pełni żadnej z wymienionych funkcji. W Unii Europejskiej stosuje się

${ }^{12} \mathrm{https} / /$ ec.europa.eu/info/strategy/priorities-2019-2024/european-green-deal/agriculture-and-green-deal_pl [dostęp: 12.10.2021].

${ }_{13} \mathrm{https} / /$ www.oecd-ilibrary.org/sites/073bdf99-en/1/2/1/3/index.html?itemId=/content/publication/073bdf99-en\&_csp_=eff68945dd337defc6e9948e27bfdfd6\&itemIGO=oecd\&itemContentType=book - rozdział 3 raportu OECD [dostęp: 12.10.2021].

${ }_{14}$ M. Forfa, Podatek rolny a rozwój gospodarstw rolnych, „Zeszyty Naukowe SGGW” 2011, nr 89, s. 75 i n.

${ }^{15}$ S. Owsiak, Kontrowersje wokót wspótczesnej polityki podatkowej-wybrane zagadnienia, w: J. Szołno-Koguc (red.), Ewolucja roli podatków i systemów podatkowych we współczesnych gospodarkach, Lublin 2019, s. 27-28 i n.

${ }_{16}$ Ibidem. Por. M. Jaszczyński, Funkcje podatków w gospodarce, „Zeszyty Naukowe PWSZ Płock" 2017, t. 25, s. 221-222. 
politykę niskich obciążeń fiskalnych produkcji rolnej ${ }^{17}$, jednak państwo nie rezygnuje z mechanizmu opodatkowania rolnictwa jako narzędzia polityki gospodarczej i społecznej. Natomiast nie budzi wątpliwości to, że konstrukcja systemu podatkowego powinna być kompromisem między celami fiskalnymi, gospodarczymi i ekonomicznymi ${ }^{18}$.

Coraz większe znaczenie zyskuje koncepcja ekologizacji systemu podatkowego. Założenia ekologizacji systemu podatkowego, jego „zazielenienia” (greening the tax system) zakładają wprowadzenie do obciążeń fiskalnych rozwiązań przyjaznych dla środowiska, a jednocześnie pozytywnie oddziałujących na rozwój społeczno-gospodarczy ${ }^{19}$. W krajach Unii Europejskiej mamy zróżnicowany system podatków i opłat ekologicznych ${ }^{20}$. Również w Polsce istnieje szereg obciążeń finansowych, które można zaliczyć do obciążeń ekologicznych, takich jak opłaty za korzystanie ze środowiska (pobór wody, odprowadzanie ścieków, składowanie odpadów, opłaty produktowe, opłaty z tytułu wyłączenia gruntów rolnych z produkcji itd.) ${ }^{21}$.

Rolnictwo, a szczególnie produkcja zwierzęca, wpływa znacząco na klimat. Hodowla zwierząt oraz stosowanie nadmiernej ilości nawozów silnie oddziałuje na środowisko i zwiększa emisję gazów cieplarnianych ${ }^{22}$. W Polsce głównym źródłem emisji gazów cieplarnianych jest nawożenie gleb rolniczych (emisje N20 z nawożenia) oraz hodowla zwierząt (fermentacja jelitowa oraz gospodarka odpadami zwierzęcymi powodujące emisję niebezpiecznego dla klimatu metanu ${ }^{23}$. Konieczne będzie zmierzenie się z tym problemem i zastosowanie odpowiednich bodźców ekonomicznych w celu ograniczenia emisji. Mechanizmy uwzględniające pożądane zacho-

${ }^{17}$ B. Hinn, D. Blandford, Taxation Concessions as instrument of Agricultural Policy, http:// ageconsearch.umn.edu/bitstream/7976/1/cp07hi01.pdf [dostęp: 12.10.2021].

${ }_{18}$ A. Paluch-Dybek, Rola podatków w zasilaniu budżetu państwa - analiza na przykładzie Polski, ,Studia Ekonomiczne” 2018, nr 2, s. 60.

19 Szerzej: M. Cieślukowski, Ekologizacja polskiego systemu podatkowego, w: J. Szołno-Koguc (red.), Ewolucja roli podatków..., s. 157 i n.

${ }^{20}$ P. Małecki, Podatki i opłaty ekologiczne w rozwiniętych gospodarczo krajach świata, „Zeszyty Naukowe AE w Krakowie” 2005, nr 668, s. 79 i n.; J. Śleszyński, Podatki środowiskowe i podział na grupy podatków wedlug metodyki Eurostatu, „Optimum. Studia Ekonomiczne” 2014, nr 3(69), s. 52 i n.

${ }^{21}$ M. Ziółko, Podatki ekologiczne w Polsce, w: P. Urbanek, E. Walińska (red.), Ekonomia i nauki o zarzadzaniu $w$ warunkach integracji gospodarczej, https://dspace.uni.lodz.pl/xmlui/ bitstream/handle/11089/19741/8-139_149-Zi\%F3\%20ko.pdf;jsessionid=B6CD85F0ECF7EEDAE1ABE426CFBBF60B?sequence=1 [dostęp: 15.10.2021]. Zob. też: B. Kryk, L. Kłos, I.A. Łucka, Podatki i opłaty ekologiczne po polsku, Warszawa 2011, s. 9 i n.

${ }^{22} \mathrm{https} / / /$ www.greenpeace.org/poland/dowiedz-sie/rolnictwo/ [dostęp: 15.10.2021].

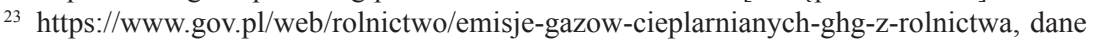
z 2018 r. [dostęp: 15.10.2021]. 
wania (np. inwestycje skutkujące ograniczeniem emisji) mogłyby znaleźć się w nowym systemie opodatkowania rolnictwa.

Wielokrotnie opowiadałem się za wprowadzeniem podatku dochodowego $\mathrm{w}$ rolnictwie ${ }^{24}$. Teza ta, bez określenia sposobu i celu wprowadzenia go, nie jest z pewnością nowatorska. Problemem jest to, w jaki sposób wprowadzić ten podatek, aby miał sens nie tylko ekonomiczny (zwiększenie wpływów do budżetu państwa), ale także ekologiczny (realizacja celów polityki klimatycznej).

Analizując problematykę opodatkowania rolnictwa w obecnej sytuacji gospodarczej i społecznej, należy przyjąć, że konieczne jest stworzenie systemu podatkowego, który będzie stymulował pożądane zachowania gospodarcze i kierunki produkcji ${ }^{25}$. Jednocześnie, aby realizować konstytucyjną zasadę wspierania gospodarstw rodzinnych, należy stworzyć narzędzia fiskalne różnicujące obciążenia gospodarstw zależnie od ich wielkości czy rodzaju produkcji, tj. ich miejsca $\mathrm{w}$ preferowanym modelu rolnictwa, którym jest rolnictwo rodzinne i rolnictwo minimalizujące wpływ produkcji na klimat.

Opodatkowanie rolnictwa podatkiem dochodowym mogłoby stymulować produkcję ekologiczną, a przede wszystkim promować model rolnictwa mającego w Polsce oparcie konstytucyjne - rodzinne gospodarstwo rolne. Gospodarstwa wielkotowarowe, nastawione na maksymalizację produkcji, a zwłaszcza wielkie zakłady produkcji zwierzęcej, nie powinny znajdować się poza systemem opodatkowania dochodu. Nie wystarczy prowadzić politykę subsydiowania zachowań pożądanych, ale należy wdrożyć mechanizmy fiskalne związane z obciążeniami zachowań niepożądanych. Przemysłowy chów zwierząt jest obecnie jedną z najbardziej szkodliwych aktywności człowieka pod względem wpływu na klimat ${ }^{26}$. Mechanizmy podatkowe mogłyby zapobiec preferencyjnemu traktowaniu tego rodzaju aktywności przez państwo. Obecnie przemysłowy chów zwierząt jest zwolniony z podatku dochodowego (z wyjątkiem chowu ptactwa i zwierząt futerkowych ${ }^{27}$ ). Nie chodzi jednak o to, aby nakładać nadmierne obciążenia fiskalne, ale by zbliżyć pod względem obciążeń tego rodzaju działalność z pozarolniczą działalnością gospodarczą.

Nietrudno wyróżnić działalność rolniczą, która jest z punktu widzenia środowiska, wpływu na klimat, jak również szeroko rozumianej moralności

24 J. Bieluk, Działy specjalne..., s. 346.

${ }^{25}$ Systematyka podatków i opłat ekologicznych: Environmental taxes: recent developments in tools for integration, Copenhagen 2000, s. 19-20, https://www.eea.europa.eu/publications/ Environmental_Issues_No_18 [dostęp: 15.10.2021]; M. Cieślukowski, Ekologizacja..., s 160.

26 J.S. Foer, Zjadanie zwierzat, Warszawa 2019.

${ }^{27}$ I to opodatkowanie jest zdecydowanie korzystniejsze niż przy nierolniczej działalności gospodarczej. 
(chów zwierząt futerkowych) niewłaściwa. Dlaczego więc nadal utrzymywane są przywileje podatkowe dla działalności, która nie ma nic wspólnego z modelem gospodarstwa rodzinnego promowanego w Konstytucji RP i wywiera negatywny wpływ na środowisko?

Działalność rolnicza powinna być objęta podatkiem dochodowym. Nie należy jednak mylić opodatkowania majątku rolnika i opodatkowania jego dochodu. Podatek dochodowy nie może zastąpić podatku rolnego ${ }^{28}$. Konieczne jest stworzenie prostej konstrukcji: podatek majątkowy, podatek od obrotu (VAT) i podatek dochodowy. Jest to powszechnie akceptowane rozwiązanie, ale, przede wszystkim z powodów politycznych, trudne do przeprowadzenia.

Wprowadzenie podatku dochodowego, obok podatku obciążającego majątek rolnika, nie zwiększy znacząco obciążeń podatkowych. W wielu gospodarstwach niskodochodowych podatek dochodowy praktycznie nie wystąpi z uwagi na ujemne wartości dochodu do opodatkowania lub mieszczenie się w kwocie zwolnionej z podatku ${ }^{29}$. Natomiast w przypadku gospodarstw wysokotowarowych obciążenie powinno znacząco wzrosnąć. Dzięki temu system miałby bardziej sprawiedliwy charakter, gdyż wysokie dochody łączyłyby się z odpowiednio wyższymi podatkami.

Do celów podatkowych należałoby wprowadzić trzy kategorie gospodarst $^{30}$. Pierwszą z nich stanowiłyby gospodarstwa socjalne, nieprodukcyjne, produkujące głównie na własne potrzeby. Powinny one być zwolnione z opodatkowania z uwagi na wysokość produkcji i co za tym idzie - niskie dochody lub ich brak. Jedynym podatkiem powinien być podatek od majątku (gruntu) o podobnej konstrukcji i wysokości jak obecnie obowiązujący podatek rolny.

Drugą kategorią powinny być gospodarstwa rodzinne, produkujące na rynek, jednak nieprzekraczające określonej wielkości produkcji, korzystające tylko $\mathrm{w}$ niewielkim stopniu $\mathrm{z}$ siły najemnej. Takie jednostki powinny być objęte opodatkowaniem podatkiem dochodowym zryczałtowanym, w roz-

${ }^{28}$ Podatek majątkowy powinien pozostać dochodem gminy. Zob. M. Wasilewski, K. Gruziel, Podatek rolny a podatek dochodowy - konsekwencje zmian dla gospodarstw rolnych, ,Roczniki Nauk Rolniczych" Seria G, 2008, t. 94, z. 2, s. 117; por. rozwiązania dotyczące innych krajów Unii Europejskiej w tym zakresie: K. Karpus, Systemy podatków lokalnych w wybranych państwach europejskich, Torun 2002, s. 13 i n.

${ }_{29}$ Zob. wyniki badań zaprezentowane przez K. Gruziel, Konsekwencje finansowe wprowadzenia podatku dochodowego w indywidualnych gospodarstwach rolniczych, „Zeszyty Naukowe SGGW, Ekonomika i Organizacja Gospodarki Żywnościowej” 2008, nr 72, s. 91-105.

30 J. Bieluk, Obciązenia podatkowe gospodarstw rodzinnych w Polsce i w Europie. Propozycje rozwiazań na przykładzie jednostek prowadzacych działalność w zakresie działów specjalnych produkcji rolnej, w: P. Litwiniuk (red.), Prawne mechanizmy wspierania i ochrony rolnictwa rodzinnego w Polsce i w innych państwach Unii Europejskiej, Warszawa 2015. 
sądnej wysokości, która nie zakłóciłaby funkcjonowania i rozwoju takiego gospodarstwa. Ryczałt może być naliczany od wielkości przychodów bądź - podobnie jak przy opodatkowaniu działów specjalnych produkcji rolnej od wielkości określonych rodzajów produkcji rolnej. Tego rodzaju system byłby systemem preferencyjnym w stosunku do opodatkowania typowej działalności gospodarczej oraz działalności rolniczej wielkich jednostek produkcyjnych, które należy zaliczyć do następnej kategorii. Rolnicy prowadzący gospodarstwa rodzinne powinni mieć możliwość wyboru, tak jak w przypadku działów specjalnych produkcji rolnej, czy rozliczać się na zasadach ryczałtowych, czy stosować rozliczenie oparte na rzeczywistych wynikach finansowych gospodarstwa. Ryczałt pozwoliłby określić preferencje państwa co do poszczególnych rodzajów produkcji, np. do produkcji ekologicznej można byłoby stosować inne stawki ryczałtowe. Byłby to przejrzysty i prosty do stosowania mechanizm.

Trzecią kategorią byłyby jednostki zajmujące się produkcją rolniczą o dużej skali i opartą w głównej mierze na pracy najemnej. Nie są one gospodarstwami rodzinnymi, preferowanymi przez Konstytucję RP, toteż system ich opodatkowania powinien zależeć m.in. od rodzaju produkcji i jej wpływu na klimat. Nie ma żadnego uzasadnienia (a tak jest obecnie) nieobjęcie opodatkowaniem podatkiem dochodowym przedsiębiorstw rolnych, takich jak fermy tuczników o wielkości produkcji liczonej w dziesiątkach milionów euro.

Takie rozwiązanie pozwoliłoby na aktywne prowadzenie polityki państwa wspierającej preferowany model rolnictwa, a jednocześnie realizację zasady powszechności opodatkowania i sprawiedliwości obciążeń podatkowych. Umożliwiłoby także wbudowanie w system podatkowy szeregu funkcji pozafiskalnych, takich jak: wspomaganie inwestycji proekologicznych, preferowanie określonych rodzajów produkcji czy wspomaganie działań w kierunku zachowania różnorodności biologicznej. Wiele działań rolników byłoby wówczas z jednej strony stymulowanych przez strumień środków unijnych, a z drugiej - wspomaganych przez mechanizmy fiskalne.

\section{Uwagi końcowe}

Trudno powiedzieć, czy bezwład związany z reformą opodatkowania rolnictwa można w obecnej sytuacji politycznej przerwać. Z pewnością jednak powiązanie obciążeń fiskalnych rolnictwa $\mathrm{z}$ jego wpływem na środowisko jest $\mathrm{w}$ dłuższej perspektywie koniecznością. Ustawodawca poradził sobie $\mathrm{z}$ określeniem modelu gospodarstwa rodzinnego $\mathrm{w}$ ramach ograniczenia 
nabywania nieruchomości rolnych w ustawie z 11 kwietnia 2003 r. o kształtowaniu ustroju rolnego ${ }^{31}$. Potrafił zdefiniować, pomijając jego nieprecyzyjność, pojęcie preferowanego modelu gospodarstwa rolnego.

Należy zatem wykorzystać system podatkowy, aby w ramach obciążeń fiskalnych wzmacniać gospodarstwa rodzinne, nastawione na rodzaj i metody produkcji najbliższe neutralności klimatycznej. Ekologizacja powinna być jednym z celów reformy opodatkowania rolnictwa ${ }^{32}$. „Zazielenienie” systemu podatkowego powinno dotyczyć bezpośrednich obciążeń fiskalnych rolnictwa, tj. podatku dochodowego, którego wprowadzenie stworzyłoby zarazem mechanizm obciążający te rodzaje działalności, które najbardziej niekorzystnie oddziałują na środowisko.

Nie ma usprawiedliwienia dla preferencji podatkowych przy produkcji rolnej wpływającej negatywnie na środowisko (np. wysokotowarowa produkcja zwierzęca). Do ustawodawcy, w ramach konsultacji społecznych, powinno należeć określenie granicy między modelowym gospodarstwem indywidualnym, traktowanym preferencyjnie, a wysokotowarową, szkodliwą dla klimatu produkcją rolną.

\section{BIBLIOGRAFIA}

Bieluk J. (2013), Dziaty specjalne produkcji rolnej. Problemy prawne, Białystok.

Bieluk J. (2015), Obciażenia podatkowe gospodarstw rodzinnych w Polsce $i$ w Europie. Propozycje rozwiązań na przykładzie jednostek prowadzacych działalność w zakresie działów specjalnych produkcji rolnej, w: P. Litwiniuk (red.), Prawne mechanizmy wspierania i ochrony rolnictwa rodzinnego w Polsce $i$ w innych państwach Unii Europejskiej, Warszawa.

Burzec M. (2018), Podatek rolny, w: P. Smoleń (red.), Opodatkowanie rolnictwa w Polsce. Weryfikacja założeń. Perspektywa zmian, Warszawa.

Burzec M., Smoleń P. (2018), Nowy model opodatkowania rolnictw w Polsce, w: P. Smoleń (red.), Opodatkowanie rolnictwa $w$ Polsce. Weryfikacja założeń. Perspektywa zmian, Warszawa.

Cieślukowski M. (2019), Ekologizacja polskiego systemu podatkowego, w: J. Szołno-Koguc (red.), Ewolucja roli podatków i systemów podatkowych we wspótczesnych gospodarkach, Lublin.

Dziemianowicz R.I. (2007), Efektywność systemu opodatkowania rolnictwa, Białystok.

Environmental taxes: recent developments in tools for integration, Copenhagen 2000, https:// www.eea.europa.eu/publications/Environmental_Issues_No_18 [dostęp: 15.10.2021].

Foer J.S. (2019), Zjadanie zwierząt, Warszawa.

${ }^{31}$ Ustawa z 11 kwietnia 2003 r. o kształtowaniu ustroju rolnego (t.j. Dz. U. z 2020 r., poz. 1655).

${ }^{32}$ Niniejszy artykuł ma tylko zasygnalizować problem, inna kwestia, wymagająca szerokich badań, to przygotowanie konkretnych rozwiązań ustawowych. 
Foer J.S. (2020), Klimat to my. Ratowanie planety zaczyna się przy śniadaniu, Warszawa.

Forfa M. (2011), Podatek rolny a rozwój gospodarstw rolnych, „Zeszyty Naukowe SGGW” nr 89.

Gruziel K. (2008), Konsekwencje finansowe wprowadzenia podatku dochodowego $w$ indywidualnych gospodarstwach rolniczych, „Zeszyty Naukowe SGGW. Ekonomika i Organizacja Gospodarki Żywnościowej” nr 72.

Gruziel K. (2008), Stan i kierunki zmian w opodatkowaniu gospodarstw rolniczych, Warszawa.

Hinn B., Blandford D. (2007), Taxation Concessions as Instrument of Agricultural Policy, http://ageconsearch.umn.edu/bitstream/7976/1/cp07hi01.pdf [dostęp: 12.10.2021].

Jaszczyński M. (2017), Funkcje podatków w gospodarce, „Zeszyty Naukowe PWSZ Płock” t. 25.

Karpus K. (2002), Systemy podatków lokalnych w wybranych państwach europejskich, Toruń.

Klein N. (2020), To wszystko zmienia. Kapitalizm kontra klimat, Warszawa.

Kryk B., Kłos L., Łucka I.A. (2011), Podatki i opłaty ekologiczne po polsku, Warszawa.

Małecki P. (2005), Podatki i opłaty ekologiczne w rozwiniętych gospodarczo krajach świata, „Zeszyty Naukowe AE w Krakowie” nr 668.

Owsiak S. (2019), Kontrowersje wokót współczesnej polityki podatkowej-wybrane zagadnienia, w: J. Szołno-Koguc (red.), Ewolucja roli podatków i systemów podatkowych we wspótczesnych gospodarkach, Lublin.

Paluch-Dybek A. (2018), Rola podatków w zasilaniu budżetu państwa-analiza na przykładzie Polski, ,Studia Ekonomiczne” nr 2.

Podstawka M. (1995), Opodatkowanie rolnictwa i perspektywy jego zmian w Polsce, Warszawa.

Śleszyński J. (2014), Podatki środowiskowe i podział na grupy podatków wedtug metodyki Eurostatu, „Optimum. Studia Ekonomiczne” nr 3(69).

Wasilewski M., Gruziel K. (2008), Podatek dochodowy w indywidualnych gospodarstwach rolniczych - koncepcja i skutki, „Zagadnienia Ekonomiki Rolnej” nr 1.

Wasilewski M., Gruziel K. (2008), Podatek rolny a podatek dochodowy-konsekwencje zmian dla gospodarstw rolnych, „Roczniki Nauk Rolniczych” Seria G, t. 94, z. 2.

Zegar J.S. (red.) (2009), Sytuacja ekonomiczna polskiego rolnictwa po akcesji do Unii Europejskiej, Warszawa.

Ziółko M. (2016), Podatki ekologiczne w Polsce, w: P. Urbanek, E. Walińska (red.), Ekonomia i nauki o zarządzaniu w warunkach integracji gospodarczej, Łódź, https://dspace. uni.lodz.pl/xmlui/bitstream/handle/11089/19741/8-139_149-Zi\%F3\%20ko.pdf;jsessionid=B6CD85F0E[F7EEDAE1ABE426CFBBF60B?sequence=1 [dostęp: 15.10.2021].

\section{SOME REMARKS ON THE TAXATION OF AGRICULTURE IN POLAND IN THE CONTEXT OF THE EUROPEAN GREEN DEAL}

\section{Summary}

The aim of the considerations is an attempt to define the role that the system of taxation of agriculture could play in the implementation of new solutions aimed primarily at minimising the impact of agricultural production on the environment. The considerations should also take into account the role of the agricultural taxation system in shaping the systemic model of 
agriculture based on family farms. In conclusion, the author proposes, among other things, that the system of taxation should be directed towards easing fiscal burdens of family farms oriented towards the type and methods of production which are closest to climate neutrality. The greening of agricultural taxation ought to be one of the objectives of the reform of agricultural taxation. It should be up to the legislator, in the framework of public consultations, to define the boundary between a model individual holding which is treated preferentially and a large-scale agricultural production that has a very negative impact on the climate.

Keywords: taxes in agriculture in Poland, European Green Deal, agricultural income tax

\section{ALCUNE OSSERVAZIONI SULLA TASSAZIONE IN AGRICOLTURA IN POLONIA NEL CONTESTO DEL GREEN DEAL EUROPEO}

\section{Riassunto}

L'articolo si propone di definire il ruolo che il sistema di tassazione in agricoltura potrebbe svolgere nel processo di attuare nuove soluzioni volte principalmente a minimizzare l'impatto che la produzione agricola ha sull'ambiente. Allo stesso tempo, le considerazioni dovrebbero tenere conto del ruolo che il sistema di tassazione in agricoltura può avere sul modello sistemico di agricoltura basato sulle aziende a conduzione familiare. Nella parte conclusiva, l'autore afferma, tra l'altro, che il sistema fiscale dovrebbe essere sfruttato anche per rafforzare le aziende a conduzione familiare che puntano sul tipo e sui metodi di produzione più vicini alla neutralità climatica. L'inverdimento della tassazione in agricoltura dovrebbe costituire uno degli obiettivi della sua riforma. Al legislatore dovrebbe spettare, previa consultazione pubblica, il compito di definire il confine tra il modello di azienda agricola individuale, da lui privilegiato, e la produzione agricola di massa con impatto molto negativo sul clima.

Parole chiave: tassazione in agricoltura in Polonia, Green Deal europeo, aziende a conduzione familiare 